\title{
The potential of varves in high-resolution paleolimnological studies
}

\author{
Achim Brauer ${ }^{1}$, P. Dulski ${ }^{1}$, C. Mangili' ${ }^{1}$, J. Mingram ${ }^{1}$ and J. LiU ${ }^{2}$ \\ 'Section 5.2 Climate Dynamics and Landscape Evolution; German Research Centre for Geosciences, Potsdam, Germany; brau@gfz-potsdam.de \\ ${ }^{2}$ Institute of Geology and Geophysics, Chinese Academy of Sciences, Beijing, China
}

\begin{abstract}
A novel approach to investigating annually laminated lake sediments combines micro-facies analyses on thin sections with high-resolution X-ray fluorescence scanning on impregnated sediments. It facilitates improved varve counting and interpretation of seasonal paleoclimate signals including extreme events and the dynamics of abrupt changes.
\end{abstract}

Varved lake sediments are important high-resolution climate and environment archives for paleolimnological investigations because they provide independently datable evidence of environmental change in response to either climatic change or human impact (Lamoureux, 2001; Brauer, 2004; Zolitschka, 2003; 2006). Such records are not only found in present-day lakes but also in paleolake deposits and allow detailed reconstructions for time intervals without any human influence (Mangili et al., 2005; Brauer et al., 2007). Varved sediments provide both an independent dating tool (e.g., Kitagawa and van der Plicht, 1998) and high-resolution proxy data. Traditional geochemical, physical and biological analyses at discrete sample intervals commonly provide data at decadal to sub-decadal resolution. Annual resolution is revealed from varve thickness measurements. A comprehensive interpretation of the latter requires profound knowledge of the seasonal composition and structure of varves because many different varve types can form depending on the climate regime and environmental conditions. The classification of varves into three major types, i.e., clastic, organic and evaporitic (e.g., Zolitschka, 2003), however, is too broad to describe all variations in varve deposition. Further details about seasonal sub-layers can be obtained by micro-facies analyses (Brauer, 2004) and provide crucial information on the seasonal signals in varve records, thereby enabling the detection of low-amplitude and short-term climate changes (Brauer et al., 2008a; b). The main limitation of micro-facies data, however, lies in their only semi-quantitative character. This problem can be overcome by integrating microscope analyses with $\mu$-XRF scanning, which allows detailed element profiling across individual varves.

\section{Methodological approach}

Direct combination of varve micro-facies data and high-resolution element scanning requires that both analyses be per-

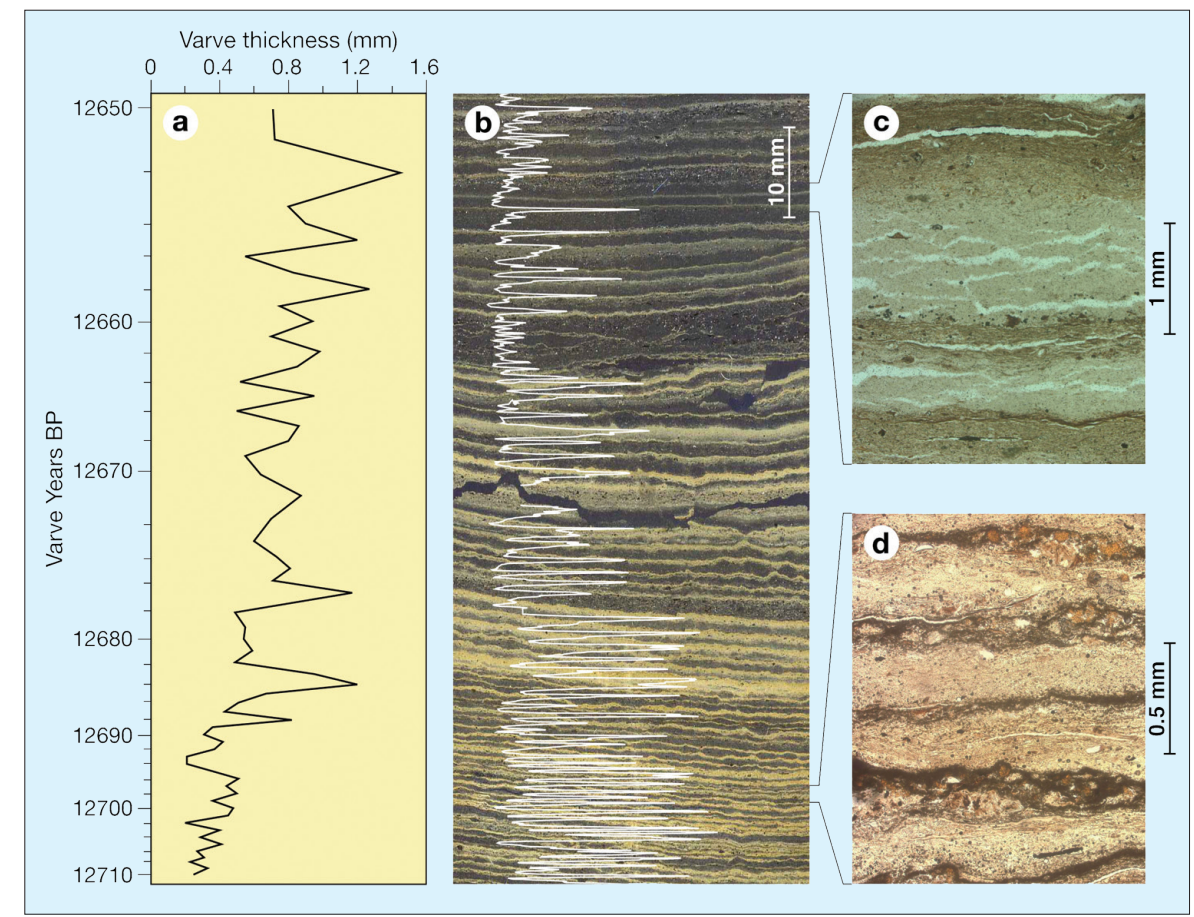

Figure 1: Abrupt micro-facies changes at the Allerød/Younger Dryas boundary (12,680 varve years BP) in the Lake Meerfelder Maar sediments. a) Varve thickness plot (note: age scale for (a) has been adjusted to fit image (b)); $\boldsymbol{b}$ ) Thin-section scan (polarized light) and superimposed Fe-profile indicating siderite (iron carbonate)-rich winter layers (light colors); thin section images (plain parallel light) of c) Early Younger Dryas varves exhibiting distinct light spring/summer diatom layers and dark layers of reworked minerogenic and organic matter and d) Late Allerød varves characterized by dark siderite layers. Figure modified from Brauer et al., $2008 a$.

formed on the same sectional plane in order to exclude spatial inhomogeneities within the sediment column. Therefore, $\mu$-XRF measurements are performed on impregnated sediment blocks that are prepared for thin section analyses. Fresh sediment slices $(10 \times 2 \mathrm{~cm})$ are impregnated with resin after freeze-drying (Merkt, 1971) or acetone exchange (Lamoureux, 2001). The impregnated sample blocks are cut along the long axis so that the cutting plane of one half can be used for large-scale thin section preparation, while the other half serves for major element scanning. Element analyses conducted in a vacuum chamber of a $\mu$-XRF spectrometer reduce the loss of radiation intensity due to absorption by air. Measurements at highest resolution have a spot size (beam diameter) of $50 \mu \mathrm{m}$ and an increment of 40 $\mu \mathrm{m}$ (width between two consecutive measurements), resulting in 5 to 30 data points per varve depending on annual sedimen- tation rate. A further advantage of analyzing impregnated samples is the perfect reproducibility of measurements even after long storage times, because changes in sediment geochemistry are prevented by impregnation.

In conclusion, parallel micro-facies and element analyses enable unambiguous identification and allocation of each peak in element variations directly to the microscopic observation. This facilitates interpretations of the observed chemical signals and provides better quantification of micro-facies changes. Using this novel approach, it is possible to improve detection of abrupt climate changes, seasonal event layer deposition and understanding of long-term changes in seasonality.

\section{Abrupt climate change}

Abrupt climate changes are a key issue in paleoclimate research (Alley et al., 2003) because understanding the processes 
and dynamics of rapid and high-amplitude climate shifts is crucial for assessing the probability of such changes in the future. The last major climatic shift at the end of the last glaciation was related to the Younger Dryas cold phase, which has commonly been connected to changes in North Atlantic thermohaline circulation triggered by major melt-water fluxes (Broecker, 2006). Detailed analyses of the onset of the Younger Dryas in the varved sediment record from Lake Meerfelder Maar (Germany) provides several lines of evidence from micro-facies and elemental changes in less than a decade from a mainly quiet, anoxic lake environment to a seasonally well-mixed and turbulent lake (Fig. 1). The five-fold increase in varve thickness is explained by both higher amounts of reworked littoral material caused by strong wave activity and pronounced diatom layers as a result of increased nutrient fluxes and remobilization. Together, these data point to a very abrupt wind shift suggesting that changes in atmospheric circulation may have played a crucial role (Brauer et al., 2008a). Similar evidence for abrupt atmospheric change has been recently reported from Greenland ice cores (Steffensen et al., 2008).

\section{Seasonal flood layers}

A further concern in the climate debate is a possible increase in flood frequencies as a consequence of global warming. Interpretation of historical records does not provide an unequivocal picture since intense human activities in river catchments have an impact on flood characteristics and may mask climatic effects. This information gap can be filled through analyses of natural flood frequency records from periods without human impact. Varved sediments allow the seasonality of past flood deposits to be deduced through analysis of their microstratigraphic position within the annual cycle of sedimentation (Mangili et al., 2005). Mineralogical and geochemical contrasts between autochthonous sediments and flood-triggered detrital matter are distinctive features of biochemical calcite varves (Lotter and Lemcke, 1999). In a long series of such calcite varves from the interglacial Piànico paleolake (Italy, southern Alps), even micro-scale flood layers could be detected at seasonal resolution (Fig. 2). These detrital layers were composed of catchment dolomite and were therefore well distinguished from their micro-facies and geochemical signatures. Preliminary results from the study of Piànico sediments indicate that, under natural interglacial conditions, the frequencies of spring and summer floods were higher
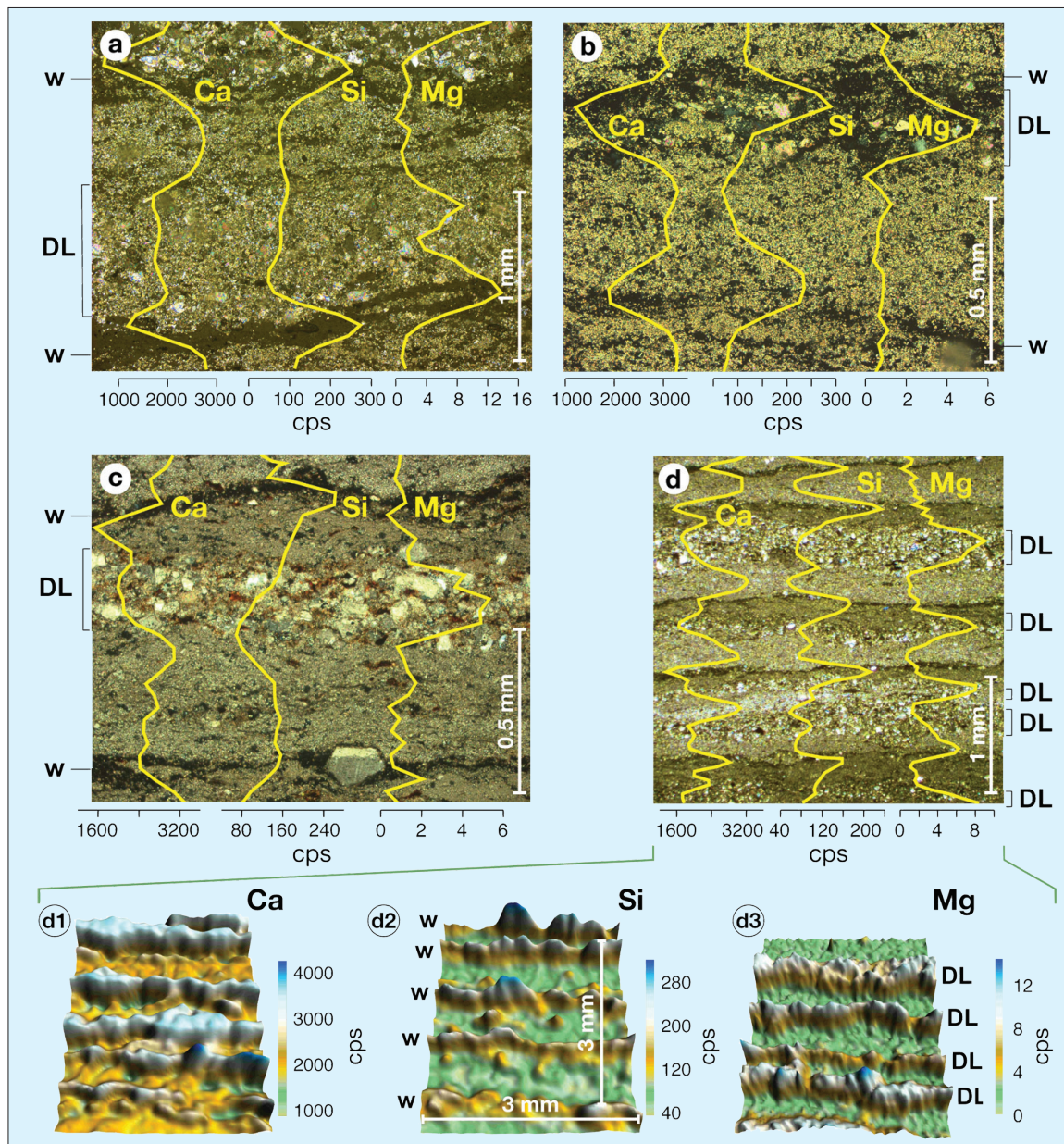

cps

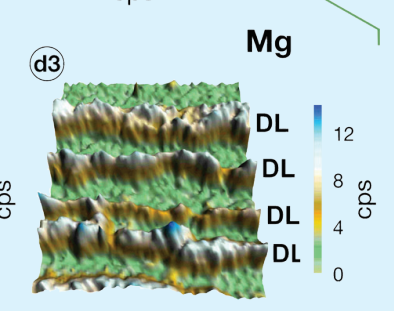

Figure 2: Thin-section images (polarized light) of varve and detrital layers with superposed $\mu$-XRF data at $50 \mu \mathrm{m}$ resolution (in counts per second, cps) for intervals of the Piànico interglacial sediments. a) Spring detrital layer (DL) above the winter layer ( $w$ ) and below the endogenic calcite layer, and profiles for endogenic calcite (Ca), siliciclastic (Si) and dolomite (Mg) detritus; b) Autumn/winter detrital layer (between the endogenic calcite and the upperwinter layer) and element profiles; c) Summer detrital layer (incorporated within the calcite layer) and element profiles; d) Succession of 4 varves including detrital layers and element profiles; d1) - d3) 3D plots exhibiting the spatial distribution of $\mathrm{Ca}$, Si, and $\mathrm{Mg}$ for the area shown in d). Detrital layers reflect past flood events and can therefore provide a record of the natural flood frequency from periods without human impact.

during times of colder climate (Mangili et al., 2007; 2005), whereas fall and winter floods did not show significant frequency changes.

\section{Long-term change in seasonality}

Many proxy records indicate that the Asian monsoon was intensified during the warm early Holocene climate. Thus, understanding seasonal effects and environmental processes during this time interval could aid a better assessment of future scenarios. A long varve record from Lake Sihailongwan in northeastern China enabled comparison of present-day with early Holocene seasonal dynamics through detailed micro-facies analyses. Modern varves were characterized by regular, distinct spring snow-melt layers consisting of local minerogenic and organic debris (Fig. 3; Mingram et al., 2004; Chu et al., 2005). Predominantly organic summer deposits with few minerogenic components were followed by thin autumn diatom layers. In contrast, varves that formed between $11-8$ cal ka BP exhibited additional layers of well-sorted, silt-sized dust deposited in spring/early summer. These dust layers were separated from the snow-melt deposits by an additional diatom bloom (Rioual et al., 2006). The occurrence of dust layers differed from varve to varve as a result of a clear inter-annual variability of the early Holocene climate. Increased clay contents in summer and winter layers further contributed to higher minerogenic sediment fluxes compared to the presentday situation (Schettler et al., 2006).

\section{Conclusions and outlook}

There is great potential for applying $\mu$-XRF element scanning to varve records, but the value of the huge amount of data produced can be significantly increased in combination with micro-facies analyses. Consequently, the major advance of this technique is in providing a broader database for more comprehensive interpretation rather than in reducing the time for investigation. A future challenge is to further extend the presently mainly sedimentological-geochemical database through comparably precise combinations with biological proxies. 


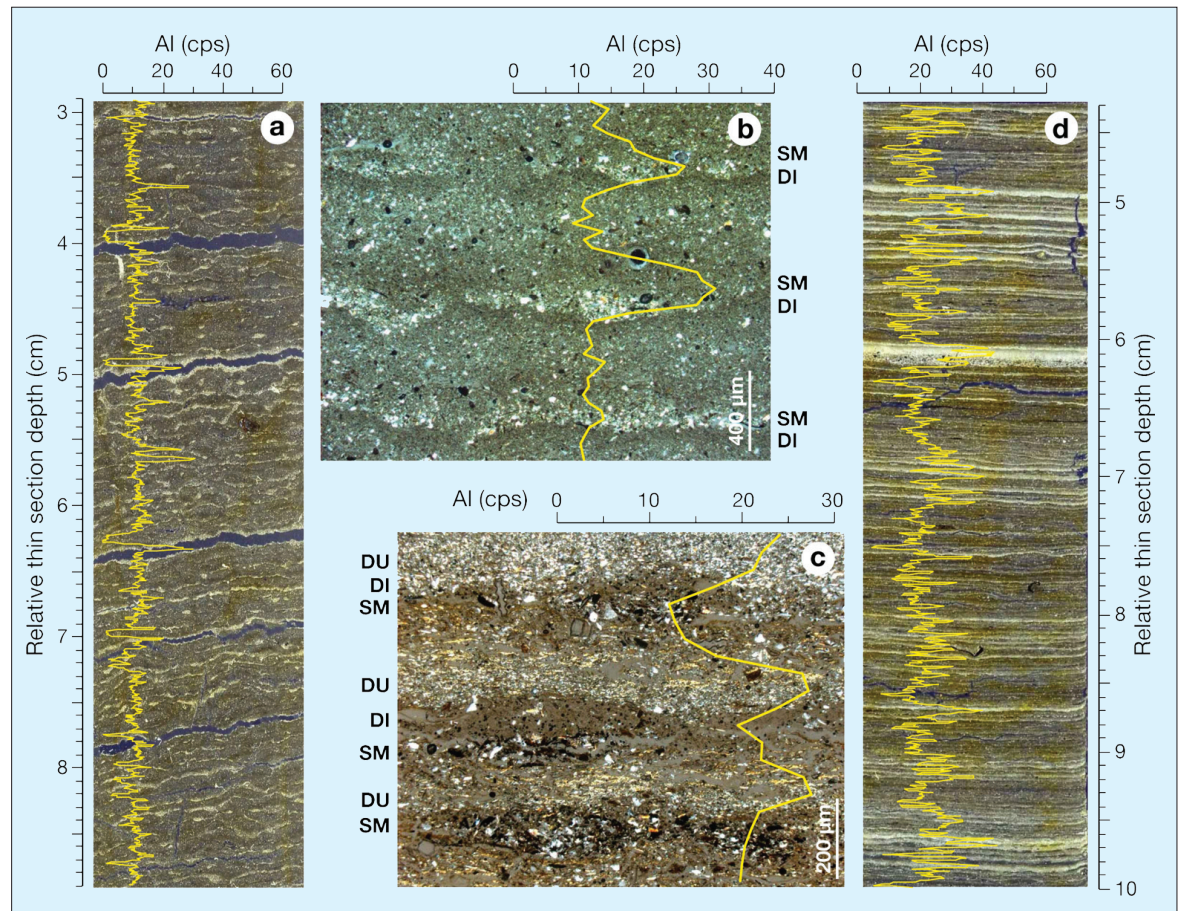

Figure 3: Comparison of modern $(\boldsymbol{a}, \boldsymbol{b})$ and early Holocene $(\boldsymbol{c}, \boldsymbol{d})$ micro-facies of varves from Lake Sihailongwan, China. a) and d) show scanned thin sections (polarized light) and superposed Al-profiles as proxy for siliciclastic detritus; note the pronounced inter-annual variability in the occurrence of dust layers (light colors); b) and c) show thin section images (polarized light) showing differences in seasonal sub-layer deposition and superimposed Al-profiles: DU - dust layer; DI - diatom layer; SM - snow melt layer. Fine-grained detrital layers indicate seasons of dust deposition and can therefore provide a record of dust transport from periods without human impact.

\section{Note}

Varve and micro-XRF Fe data from Lake Meerfelder Maar are available from the NOAA/WDC Paleo archive: ftp://ftp.ncdc.noaa.gov/pub/ data/paleo/paleolimnology/europe/germany/ meerfelder-maar2008.txt

\section{References}

Brauer, A., Haug, G.H., Dulski, P., Sigman, D.M. and Negendank, J.F.W. 2008a: An abrupt wind shift in Western Europe at the onset of the Younger Dryas cold period, Nature Geoscience, 1: 520-523.

Brauer, A., Mangili, C., Moscariello, A. and Witt, A., 2008b: Palaeoclimatic implications from micro-facies data of a 5900 varve time series from the Pianico interglacial sediment record, Southern Alps, $\mathrm{Pa}-$ laeogeography Palaeoclimatology, Palaeoecology, 259: 121-135.

Mangili, C., Brauer, A., Moscariello, A. and Naumann, R., 2005: Microfacies of detrital event layers deposited in Quaternary varved lake sediments of the Piànico-Sèllere Basin (northern Italy), Sedimentology, 52: 927-943

Mingram, J., Allen, J.R.M., Brüchmann, C., Liu, J., Luo, X., Negendank, J.F.W., Nowaczyk N. and Schettler, G., 2004: Maar- and crater lakes of the Long Gang Volcanic Field (N.E. China) - overview, laminated sediments, and vegetation history of the last 900 years, Quaternary International, 123-125: 135-147.

Schettler, G., Mingram, J., Liu, Q., Stebich M. and Dulski, P., 2006: EastAsian monsoon variability between 15000 and 2000 cal. yr BP recorded in varved sediments of Lake Sihailongwan (northeastern China, Long Gang volcanic field), The Holocene, 16(8): 1043-1057.

For full references please consult:

www.pages-igbp.org/products/newsletters/ref2009_3.htm

\section{Fourier transform infrared spectroscopy: Rapid, quantitative analysis of biogeochemical properties of lake sediments}

Peter Rosén ${ }^{1}$, H. Vogel ${ }^{2}$, L. Cunningham ${ }^{1,3}$, N. Reuss ${ }^{4}$, D. Conley and P. Persson ${ }^{6}$

${ }^{1}$ Climate Impacts Research Centre, Umeå University, Abisko, Sweden; peter.rosen@emg.umu.se

${ }^{2}$ Institute for Geology and Mineralogy, University of Cologne, Germany; ${ }^{3}$ Department of Geography and Geosciences, University of St Andrews, Scotland; ${ }^{4}$ Freshwater Biological Laboratory, University of Copenhagen, Hillerød, Denmark; ${ }^{5}$ GeoBiosphere Science Centre, Quaternary Sciences, Lund University, Sweden; ${ }^{6}$ Department of Chemistry, Umeå University, Sweden

\section{FTIRS analysis of small sediment quantities can provide fast, inexpensive and high-resolution records of organic and inorganic carbon, nitrogen and biogenic silica that are essential for detailed paleoclimate and environmental reconstructions in long sediment records.}

Continuous paleoclimate records from the continental realm covering several climatic cycles are increasingly recognized as important archives of environmental responses to climatic change. Given anthropogenic global warming, this information is particularly crucial for the understanding of natural climate variability. Over the past decade, the recovery of long sedimentary records from terrestrial sites and, in particular, large and ancient lakes, has been made possible by the International Continental Drilling Program (ICDP) and associated partners. The most recent example is Lake El'gygytgyn, where the longest (>300 m, 3.6 Ma) and probably most continuous terrestrial paleoclimate archive has been recovered during the spring 2009 deep drilling campaign. In order to extract information on climatic and environmental change from these long records at a high temporal resolution, fast, cost-efficient and, preferably, non-destructive methods are required. X-ray fluorescence scanners and multi-sensor core loggers can provide such highly resolved, qualitative and semi-quantitative information on the inorganic geochemistry, mineralogy, and magnetic properties of sediments. Non-destructive methods providing quantitative information on biogeochemical properties, however, have not been available until present. Within the initial Lake El'gygytgyn deep drilling project, and preliminary studies for potential deep drilling projects at Lake Ohrid and Pingualuit Crater Lake, we tested the potential of Fourier transform infrared spectroscopy (FTIRS) as analytical method for the quantitative determination of bio- geochemical properties. The great potential of the FTIRS technique comes from the large amount of information on minerogenic and organic substances provided by the FTIR spectra. Most importantly, it is a rapid, cost-saving technique, which only requires very small amounts $(0.01 \mathrm{~g}$ dry weight) of sample material.

\section{Analytical background and principles of FTIRS}

The basic principle of the FTIRS technique is that infrared radiation stimulates molecular vibrations and, as a consequence of the quantum mechanical behavior, this radiation is absorbed at specific wavenumbers. Major changes in organic and inorganic properties present in sediment can therefore be qualitatively identified from the FTIR spectra. For example, the band 


\section{Full Reference List:}

Alley, R.B. et al., 2003: Abrupt climate change, Science, 299: 2005-2010.

Brauer, A., 2004: Annually laminated lake sediments and their palaeoclimatic relevance. In: Fischer, H., et al. (Eds), The Climate in Historical Times. Towards a Synthesis of Holocene Proxy Data and Climate Models, Springer Verlag, 109-127.

Brauer, A., Allen, J.R.M., Mingram, J., Dulski, P., Wulf, S. and Huntley, B., 2007: Evidence for last interglacial chronology and environmental change from Southern Europe, Proceedings of the National Academy of Science, 104: 450-455.

Brauer, A., Haug, G.H., Dulski, P., Sigman, D.M. and Negendank, J.F.W., 2008a: An abrupt wind shift in Western Europe at the onset of the Younger Dryas cold period, Nature Geoscience, 1: 520-523.

Brauer, A., Mangili, C., Moscariello, A. and Witt, A., 2008b: Palaeoclimatic implications from microfacies data of a 5900 varve time series from the Pianico interglacial sediment record, Southern Alps, Palaeogeography Palaeoclimatology, Palaeoecology, 259: 121-135.

Broecker, W.S., 2006: Was the Younger Dryas triggered by a flood? Science, 312: 1146 - 1148.

Chu, G., Liu, J., Schettler, G., Li, J., Sun, Q., Gu, Z., Lu, H., Liu, Q. and Liu, T., 2005: Sediment Fluxes and Varve Formation in Sihailongwan, a Maar Lake from Northeastern China, Journal of Paleolimnology, 34: 311-324.

Kitagawa, H. and van der Plicht, J., 1998: Atmospheric radiocarbon calibration to 45,000 yr B.P.: Late Glacial fluctuations and cosmogenic isotope production, Science, 279: 1187-1190.

Lamoureux, S.F., 2001: Varve chronology techniques. In: Last, W.M. and Smol, J.P. (Eds), Developments in Paleoenvironmental Research (DPER), Vol. 2 - Tracking Environmental Change Using Lake Sediments: Physical and Chemical Techniques, Kluwer, Dordrecht, 247-260.

Lotter, A.F. and Lemcke, G., 1999: Methods for preparing and counting biochemical varves, Boreas, 28: $243-252$.

Mangili, C., Brauer, A., Moscariello, A. and Naumann, R., 2005: Microfacies of detrital event layers deposited in Quaternary varved lake sediments of the Piànico-Sèllere Basin (northern Italy), Sedimentology, 52: 927-943.

Mangili, C., Brauer, A., Plessen, B. and Moscariello, A., 2007: Centennial-scale oscillations in stable oxygen and carbon isotopes of endogenic calcite from a 15500 varve year record of the Piànico interglacial, Quaternary Science Reviews, 26: 1725-1735.

Merkt, J., 1971: Zuverlässige Auszählungen von Jahresschichten in Seesedimenten mit Hilfe von Groß-Dünnschliffen, Archiv für Hydrobiologie, 69: 145-154.

Mingram, J., Allen, J.R.M., Brüchmann, C., Liu, J., Luo, X., Negendank, J.F.W., Nowaczyk N. and Schettler, G., 2004: Maar- and crater lakes of the Long Gang Volcanic Field (N.E. China) overview, laminated sediments, and vegetation history of the last 900 years, Quaternary International, 123-125: 135-147.

Rioual, P., Chu, G., Han, J., Mingram, J., Liu, Q., Schettler, G. and Liu, J., 2006: Holocene climatic and limnologic changes at Sihailongwan maar lake (Northeastern China) as indicated by diatom remains: preliminary results, HOLIVAR Natural Climate Variability and Global Warming, London.

Schettler, G., Mingram, J., Liu, Q., Stebich M. and Dulski, P., 2006: East-Asian monsoon variability between 15000 and 2000 cal. yr BP recorded in varved sediments of Lake Sihailongwan (northeastern China, Long Gang volcanic field), The Holocene, 16: 1043-1057.

Steffensen, J.P. et al., 2008: High-Resolution Greenland Ice Core Data Show Abrupt Climate Change Happens in Few Years, Science, 321: 680-684.

Zolitschka, B. 2003: Dating based on freshwater and marine laminated sediments. In: MacKay, A. et al. (Eds), Global Change in the Holocene, Edward Arnold Publishers, London: 92-106.

Zolitschka, B. 2006: Varved lake sediments. In: Elias, S.A. (Ed.), Encyclopedia of Quaternary Science, Amsterdam, Elsevier, 3105-3114. 